\title{
STRATEGIC DETERMINANTS FOR THE DEVELOPMENT OF TRADITIONAL HANDICRAFT INDUSTRY OF ALGERIA
}

\author{
${ }^{1}$ Fatiha Bouziane, ${ }^{2}$ Azizul Hassan \\ $\mathrm{PhD}$ Researcher University of Algiers, Algeria \\ PhD Researcher Cardiff Metropolitan University, United Kingdom
}

\begin{abstract}
The traditional handicraft industry is an important asset to support and help developing the tourism sector of a country. Such conventional products appear as a part of the tourism industry of any country. Algeria has been working for promoting this sector at least for the last few years. This paper thus, attempts to uncover the present situation of this sector in Algeria to identify the achievements that resulted from the taken initiatives. This research is followed descriptive analytical method supported by a theoretical explanation of traditional trades in tourism and the pertaining problems of this sector in the Algerian perspectives. The study then went on analyzing the plans that were taken between the period of 2003-2020 to develop the sector. These plans envisioned to upgrade the competitiveness of this sector by encouraging more entrepreneurial initiates and trainings. These plans also aimed to engage a group of mediators to liaise with the craftsmen and central management bodies of the Algerian government. These plans are said to have achieved considerable positive outcomes especially, in creating a solid ground for this sector's development and by creating more jobs. Still, the lack of consumer demand remains an issue. On the other side, funding also becomes the other concern for this sector's development. This study thus, stresses on appropriate action for ensuring better return from this sector by more funding and strategic policy suggestions.
\end{abstract}

\section{KEY WORDS}

Algeria, handicraft, traditional industries, tourism, strategy

\section{INTRODUCTION}

Traditional handicraft industry remains as an indispensable element of a country's tourism promotional activities. This industry evidently supports tourism. If traditional handicraft industry develops, tourism also flourishes. Traditional handicraft industry sector reflects the heritage, history, customs and authenticity of a society and civilization. Even when, a tourist cannot fully afford accessing tourism products, they can get traditional products. Traditional handicraft industry plays crucial roles to promote and market a country's thriving tourism capacities. This also represents civilizations as supported by creations and traditional manufacturing. Traditional handicraft industry also nurtures natural places those behold civilizations. Algeria aimed to develop its tourism sector by upgrading the traditional handicraft industry and formulated a set of development strategies. This study particularly attempts to outline the development strategy of traditional handicraft industry of Algeria followed by the achievements. This study mostly relies on descriptive analytical method highlighting studies conducted in the Algerian traditional handicraft industry. The study partly relied on statistics and data generated by the relevant ministry to display and analyze the development of this sub-sector. The research stresses on constructing a conceptual framework of traditional handicraft industry through a workable definition, modes of practice, crafting activities and economic importance. Also, an assessment is followed on traditional handicraft industry development in Algeria during the period 2003-2010,

DOI: $10.5121 /$ ijmvsc.2016.7101 
International Journal of Managing Value and Supply Chains (IJMVSC) Vol. 7, No. 1, March 2016

problems of this sub-sector, action plan for sustainable development of traditional handicraft industry prospects for 2010. In addition, this research understands the handicraft sub-sector in Algeria during the period 2010-2020, shortcomings recorded after 2010 evaluation scheme, the Crafts Horizon 2020 Strategy and strategic assessment of the handicraft sub-sector prospects by 2020.

\section{CONCEPTUAL FRAMEWORK OF TRADITIONAL HANDICRAFT INDUSTRY}

This paper looks for a working definition of traditional handicraft industry and its importance in the Algerian economy.

Definition of traditional handicraft industry: There are a good number of definitions of traditional handicraft industry that differs from one to another as well as from one ground to the other. However, this study will concentrate on definition as offered by the United Nations Conference on Trade and Development, the UNESCO and the the Algerian legislations. The United Nations Conference on Trade and Development has defined traditional handicraft industry in 1969 as, the expression of products produced by hand with the help of tools, simple means or equipments from craftsmen; most part of the work is done either by using hands or foot. On the other side, traditional handicraft industry led handmade products are characterized as, the traditional form or art form that reflects the characteristics and traditions of the country of origin, where artisans often practice their work at home (Sdiqi, 2002). The UNESCO offered a definition of traditional handicraft industry in 1997 as, 'The traditional products if they are made by artisans manually, and / or by helping hand machine or even mechanical, provided that they constitute a contribution for manual craftsman most important in the final product compound, produces this material without specifying the quantity, and the use of raw materials derived from permanent natural resources. The special nature of traditional products result from their different characteristics, and that makes it important for use, cosmetic, artistic, creative and cultural, is what makes the traditional product combines social and economic terms alike' (Shiban, 2009). The Algerian legislature also offered a definition of traditional handicraft industry through the Decree No. 9601 on the 10th January, 1996. The set rules that govern traditional handicraft industry and crafts are: 'the traditional handicraft industry and crafts are all production activity or creativity, transformation or art restoration, maintenance or repair or performance of service dominated by manual labor and exercise mainly durable, and in a stable or a mobile form or fairs, or individual how or in a cooperative and traditional crafts of the industry or enterprise and traditional crafts of the industry' (Order No. 01-96, 4). Thus, traditional handicraft industry can be defined as products dominated more by manual labor than machines, which reflect the characteristics and traditions of a particular community and the symbols of its tradition or heritage.

\section{Practice Modes and Activities of Traditional Handicraft INDUSTRY AND CRAFTSMANSHIP IN ALGERIA:}

This has been exercised in different ways (i.e. individually, mini or small to medium-sized enterprise). According to the General Secretariat of the Government of Algeria, (1996) first, individual craftsman was defined for the first time in Article 3 of Law No. 82-12, dated the 28th August, 1982. This contained the basic law of craftsmanship. This concept was amended in 1996 by the Decree 96-01 as: 'Every natural person registered in the register of the traditional handicraft industry and Crafts and practiced traditionally active than the above-mentioned activities, prove himself qualified and shall direct the implementation of the management activity and run it and take responsibility'. Second, cooperative handicraft and crafts as a company was formed by the civilians. This was based on the feature to join as having only craftsmanship identity. This cooperative aimed to accomplish all operations and performance of services that would contribute towards direct or indirect development activities of traditional craftsmanship. Also, this 
supported to benefit its members and their exercises collectively. The cooperative helped its collaborators having equal rights regardless of their share value in seed capital as well as, nonclassification of members on the basis of their joining date in this cooperative is in order no. 0196. Third, traditional handicraft industry entrepreneurship and craftsmanship are divided into two types as: A. traditional handicraft industry entrepreneurship as every enterprise is comprised of a form specified by the Algerian commercial law. These are available with characteristics as, traditional crafts industry practices and activities; unspecified wage-worker operation; management is overseen by a craftsman or a teacher craftsman. B. Materials and services craft production entrepreneurship as each enterprise is established in accordance with a form specified by the Algerian commercial law with characteristics as: production or conversion activity exercise, materials and services craftsmanship service maintenance or repair; permanent salaried workers or makers operation that should not exceed 10 in number as: the Head of Entrepreneurship, people who have family ties with the President. On the other side, professionals should not exceed 03 in number and connecting them with entrepreneurial contract apprenticeship; administration is supervised by a craftsman or craftsman teacher, or with the participation of craftsman or run at least another technician to governing the business in case of absence of the President craftsman in order no. 01-96.

\section{ECONOMIC IMPORTANCE OF TRADITIONAL HANDICRAFT INDUSTRY:}

Traditional handicraft industry contributes to the national economy as: contribution to the GDP from traditional handicraft industry achieves an important part; value-addition is higher compared to other sectors, relying more on manual labor and local resources, traditional handicraft industry contributes to increased national wealth reflecting the economic growth. For example, contribution of traditional handicraft industry in Tunisia increased by 3\% and in Morocco by $15 \%$, where Europe has seven million traditional handicraft industry and craft enterprises employing 22 million workers. Traditional handicraft industry helps to create jobs by engaging a large number of labors. This industry contributes to increased state revenues from exports. Traditional handicraft industry is a productive sector characterized by offering important economic returns from small investments. Traditional handicraft industry delivers competitive advantages comparing to other countries and provides a permanent revenue source. For example, the Algerian export capacity amounted to more than three billion US\$ in France and Italy in 1997, US\$ 206 million in Tunisia in 1999 equivalent to 3.5\% of all exports (Ben Amoudi, 2012). The value of traditional handicraft industry in tourism sector plays an important role in strengthening and promotion. Tourists seek to discover and learn the culture, civilization and heritage of a country through the acquisition of their traditional products. The reduction of rural exodus creates a kind of balance in demographic distribution. Income distribution in rural environment by establishing mini- traditional handicrafts industry allows easing demographic pressure on cities. Traditional handicraft industry also leads to optimum utilization of human resources, contributes to cover the basic needs of consumers and supports existence of traditional handicraft industry of a country (Sdiqi, 2002).

\section{Traditional HANDiCRAFT IndUSTRY IN AlgERIA DURING 2003-2010:}

This paper at first shows the basic issues that this sub-sector faced between 2003-2010. Discussions then address the implementation aspects and achieved results of this development plan.

Traditional Handicrafts Industry Issues in Algeria: Algeria's traditional handicrafts industry is facing many problems and obstacles preventing it from occupying the best fitting place. The most recalled issue is the inappropriate working conditions. Most of the traditional handicraft industries are situated in poor working environments using unprofessional practices. Also, the 
absence of better security and hygiene conditions act as barriers to organized and developed practices. In addition, tools and gear users are mostly unfit having worn and deteriorated equipments.

In narrow artisan workshops, inexperienced artisans very often make the product out of use in terms of either too small or too big in size. Lack of entrepreneurship among craftsmen pushes Algeria to rely more on apprenticeship. These apprentices are commonly far more away from special training sessions in both management and marketing. This lack leads to fail the improvement of mechanical functioning and product development. Only a few of them fall within framework of the project GERME. Pricing becomes the other issue, when artisan claims high production costs relating to imported raw materials. Also, other costs as taxes and rent also lead to higher product prices. This declines quality comparing with other counterparts in global market places. All these issues make the traditional handicrafts industry becoming unable to the face of competition challenges (Ben Zaror, 2007). Quality is a very important issue in this industry. Artisans quest to adapt to market changes in the light of consumer tastes, their environment, their living standard and culture. Good quality ensures product authenticity and outlines historical and traditional treasures. Such products become responsive to meet the set standards of various markets (Ben Zaror, 2004).

Issues need to be eliminated in order to ensure economic profitability and acceptable local and international reputation and enabling the industry to compete. Contractor craftsmen must invest to generate ideas for product development to make enough success. Availability of competitive products in Algeria's traditional handicrafts industry can escalate the product quality level. The artisans need to participate in international events not only to show their product samples, but also to sell their samples. However, they do not get this opportunity very often. This results that they do not get orders throughout the year applying higher price tags (Shiban, 2009).

Also, the lack of excellence and structures of vocational training, the lack of handicraft training facilities become barriers to allow craftsmen completing their works perfectly and on time. Inappropriate use of raw materials produces low quality products. Intersecting traditional handicrafts industry from rest other economic sectors as manufacturing, tourism, construction and even agriculture leads to lose its significance in the national economy. An acceptable interdependence between diverse economic sectors is important. Such integration can ensure taking full advantages of these economic sectors that can be termed as external effects (Saadoun, 2003).

Artisans' inability to manage shopping spaces requires effective intervention of local administration. This should favor them getting granted access to traders to collect more revenues. Despite the fact that artisans do not have to necessarily rely on the amount generated as valueaddition, still they need to place proper attention to this. Also, artisans do not have to involve in constructing buildings for heritage representation, but they can obviously contribute in activating the tourism sector. They can reduce costs by using locally produced raw materials and local labors (Shiban, 2009).

Artisans are expected to become the contractor of revitalized heritage of a country. Market research can be conducted aiming to learn available marketing and exporting opportunities. As well as to manage scopes to participate in salons and international exhibitions that should provide scopes to expand the overseas market for craftsmen.

In order to address and eliminate issues related to the well-being of traditional handicrafts industry, both marketing and sample displaying capacities need to be fully exploited. To support these artisans and craftsmen, an action plan has been developed in 2003 for the sustainable development of this traditional handicraft industry. This plan should capitalize and maximize benefits from this sub-sector by 2010 . 
International Journal of Managing Value and Supply Chains (IJMVSC) Vol. 7, No. 1, March 2016

\section{Action Plan for Sustainable Development of Traditional HANDICRAFTS INDUSTRY FOR 2010:}

Before 2003, traditional handicrafts industry did not have a major role to play to develop the country. When, traditional handicrafts industry represented more or less $10 \%$ to $20 \%$ of total labor force of a country including industrialized countries, in 2002, artisans represented $1.55 \%$ only of the total labor force of Algeria. Artisans need to be incorporated with development process of a country. For this purpose, an ambitious program was prepared targeting to exploit prospects of this sector by 2010 . The aims of this program were to: directly promote activities of traditional handicrafts industry; reforming craftsmanship; strengthening local capacities to frame traditional handicraft industry; improving the legal and regulatory system. According to the Ministry of Small and Medium-sized Enterprises and Traditional Industries of Algeria (2009), this sub-sector experienced development during this period confirming efficacy of this program. The number of registered craftsmen rose by $84 \%$ within four years, where the number was 63,500 in 2002 and 150,000 in 2008.

\section{Assessment And Outcome of this ACtion Plan:}

This study explores the results achieved from applying this action plan by a set of indicators. According to the Ministry of Tourism and Handicraft of Algeria (2011), this action plan helped to create opportunities and employment. This action plan as executed from 2003-2-10, helped in making at least 185,000 craftsmen till 2010. Handicraft activities have also been expanded within this time period. The action plan assisted in upgrading traditional handicrafts industry products and services. Promotional activities as part of the action plan managed to receive considerable attention from concerned parties. Thus, artisans and craftsmen availed the opportunity to participate in a number of local, national and international shows and exhibitions ensuring their permanent and continued presence. As an outcome of effective product profiling, excess market share, knowledge generation of the artisans' and exporting strategies, this sub-sector recorded one billion Algerian Dinars between 2007 to 2008.

As direct outcome of this action plan, crude production of traditional handicrafts increased from 106 billion Algerian Dinars in 2008 to 140 billion Algerian Dinars in 2010. This means that crude production has risen by $32 \%$, equivalent to an annual growth of $15 \%$. The development of grassroots production reflects a strengthened traditional handicraft sector. This action plan supported an extension of basic structures to strengthen the sector. This action plan resulted to direct economic growth for the period 2005-2009. This period also witnessed the completion of 81 structural facilities for training and promotion in favor of artisans in various regions of the country, while the financial envelope for this program reached to 3.96 billion Algerian Dinars.

This action plan also helped to promote spaces for well-being of traditional handicrafts industry. Basic purpose of of this action plan was to improve services to be provided to craftsmen. Traditional handicrafts industry has been benefited from the rise of a number of institutions as developed within this action plan. This action plan helped to form a good number of regional Chamber of Commerce. The number of such chambers amounted to 48 by the middle of 2009 with an average of one chamber in each province.

Entrepreneurial development as outcome of this action plan was an added success. Since 2004, this sub-sector tried to adopt economic strategies for expanding craftsmanship. Based on accompanying configuration, this sub-sector got 48 regional Chamber of Commerce with an establishment and operation contract under the supervision of the International Bureau of Labor. This sub-sector has been able to accommodate more than 11,000 craftsmen than six years earlier and holding projects in various craft activities and mini-contracting. 
This action plan helped in improving general livelihood and performance of the craftsmen. The plan helps to develop displaying capacities and vocational training as offers to young people's wishing to obtain skills through training. Handicrafts teachers were given training and certificates to teach traditional handcraftsmanship, or to support the establishment of updated job profiles.

Display facilities provide continued training for craftsmen or for those having special projects (Article CREE) that need special training courses. The action plan also involved those having involvement in running institutions (Germe), in order to develop training capacities of the artisans. The study focused on 2522 craftsmen having new projects and attended over 163 seminars titled 'How to Create a Foundation', organized in all over Algeria.

According to the National Chamber of Industry and Traditional Crafts (2003), economic recovery scheme as adopted for the period of 2005-2009 witnessed the completion of 90 structure for activities, training and promotion in favor of artisans from various parts of the world. The scheme also witnessed the building of 50 rooms for traditional handicrafts industry, 10 local skills development centers, 7 Centers for traditional handicrafts industry, 6 centers for configuration/production. Also, the scheme added the grant of 23,000 shops at municipality level until the end of September, 2009. Within this programs' framework, 100 stores in each municipality has also been built.

\section{Traditional Handicrafts Industry in Algeria during the Period 2010-2020}

In this part of the study, imperfections are recorded through evaluation of the Action plan of 2010. The study then looks at strategies those are applied during the period 2010-2020. At later stage, the study attempted to make an evaluation.

Shortcomings recorded after making evaluations of the Action plan of 2010 are diverse. Assessment of the Action Plan for Sustainable Development of Traditional Handicrafts Industry of 2010 showed that active role of traditional handicrafts industry can be important in economic, social and cultural development of a country as Algeria. Conventional manufacturing industry has managed to overcome the recent recession experiences and a new start heralds that the prospects can be promising. However, many of the shortcomings still prevent the attainment of all the objectives underlined in promote Algeria's traditional handicrafts industry. Out of all these, one of the key obstacles is miss-communication between the various support groups. These groups are the National Fund to Upgrade Traditional Manufacturing Activities, CNAC, ANSEJ, ANGEM, traditional handicrafts industry and few others. Lower level of follow-up, evaluation and surveillance of projects can benefit support mechanisms of a set of strategies. Excessive and unnecessary dependency on state benefit can weaken the spirit of entrepreneurial initiatives and effectiveness. There are different support mechanisms. However, the unemployed category seems to have preferences in action plans as excluded craftsmen. This is important to determine the maximum age to 40 years for ANSEJ and 55 years for CNAC's. Limitations of traditional handicrafts industry are meant to hinder deserved benefits of the National Fund for Technical Support to Upgrade Traditional Handicrafts industry. Inadequacies of formulas and methods to ensure bank financing should help micro-enterprises. This is essential to allow unregistered artisans to get bank financing. Identify funding ceiling for some funding mechanisms is also important. This is vital to ensure success of the Sustainable Development of Traditional Handicraft Industry for 2010 and to minimize shortcomings that prevent desired achievements of set objectives of this sub-sector to develop strategies for the development of the traditional handicrafts industry by 2020 . 


\section{STRATEgIES TO DEVEloP Traditional HANDICRAFTS INDUSTRY - 2020}

This set of strategies emphasizes the contribution of traditional handicrafts industry activities for local development of the country. Setting goals to develop competitiveness of this sub-sector and its abilities to produce resources and create jobs are vital. Contributions of this sub-sector to export and economic integration between various economic branches are also crucial. On the other hand, the acceleration of economic growth through product intensification, promotion, marketing, management and organization can also become potential for local development.

According to the Algerian Ministry of Tourism and Traditional Industries (2011), traditional handicrafts industry seeks to achieve three main objectives as first, to create 230,000 new activity craftsman; and to create 570,000 new jobs to achieve the 960,000 job inventory level; second, to reach 7\% of the working labor force by 2020; third, to achieve the crude production level of 535 billion Algerian Dinar. These goals were attempted to achieve through working and focusing on many themes.

One of the main themes of traditional handicrafts industry development scheme by 2020 is to achieve set objectives. First, to develop production and competitiveness. Efforts need to be taken to strengthen and promote the production of traditional handicrafts industry. Handicrafts activities are based on some key factors as: improving production through modernization of production techniques, preparation and implementation of studies and technical assistance for the benefit of craftsmanship; improving the configuration process especially through apprenticeship training that should contribute to the improvement of productivity and quality of craft activities; designing and implementing the rehabilitation program of handicraft enterprises; strengthening institutional capacities to follow technical and market development by adopting modern design techniques to reach an appropriate products in line based on market demands; motivating traditional handicrafts enterprises to improve competitiveness, in terms of quality, costs and prices.

Second, developing the entrepreneurship. Traditional handicrafts industry has to adopt entrepreneurial development program as good organizational management that must be evaluated and strengthened through the provision of appropriate entrepreneurial atmosphere, where creative enterprises can grow better.

Third, export development. Traditional handicrafts industry products requires access to foreign markets that necessarily needs some basic actions as: to enhance export capabilities and identify possible exporting destinations and target the most promising markets; to find commercial information and terms to get access to markets, especially technical standards; to direct assistance ship to enterprises for making more exports.

Fourth, preparation and application of standards for traditional handicrafts industry. Maintaining an acceptable standard becomes one of the essential elements within institutional frameworks. Factor trade-off and a new arena of competitiveness to achieve set goals have also become strategic standard meaning that traditional handicrafts industry development becomes an importance. The application of artisan and institutional craft quality standards can make the industry recognized from technical regulations. This provides customers with quality guarantees and builds trust among them.

The development and implementation of standards in traditional handicrafts industry is one of the foundations of traditional handicrafts industry development scheme by 2020. In this context, this scheme will work on an ambitious standardization of products and services programs for the dissemination of standardization tools and different standard, geographical origin label, certification, and labeling of individual and/or collective self-sign etc. For this, a scheme for the valuation of traditional products industry will be developed that requires to mandatorily put the seal 'Made in Algeria' on products and packaging. Establish a system to ensure the quality and 
authenticity of the brand through security sign labeling. This should reduce possibilities to tamper product origin source, carries well-known specifications and determines the original product label of different regions of Algeria.

In order to achieve goals of the strategy of traditional handicraft industry development by 2020 , there should be a set of mechanisms and tools to be developed mandatorily for it. One of the important points to follow is to develop mediation functions. Traditional Handicrafts Chambers of Industry space is preferred as mediator par excellence for the implementation of traditional handicrafts industry development programs. It constitutes a forum to defense interests of craftsmen and their concerns to inform public authorities. This should help to better formulate development programs and strategies. Based on assessment that is subjects of these institutions, it is beneficial to introduce a series of structural, tasks and methodical reforms. The tasks, means and methods of work can even commensurate with aspirations of the scheme with prospects for 2020.

The development of local production systems is important. This system meets a group of artisans actively staying in the same profession, in the same region, has an exchanging mind, neighborliness, cooperating relationship and a base of trust. Proper application of these mechanisms depends on availability, especially in economic revitalization skills and industrial scopes.

Economic revitalization of local production system can facilitate a series of tasks as, building productive organizations by activating synergies between relevant sectors. This can generate an atmosphere of trust and promote cooperative networks between institutions. Also, this can formulate collective strategies through a participatory diagnosis followed by preparation of a set of development strategies and agreed action plan. This can support to complete joint ventures and structures for more feasibility. This can also search for sources of funding and project implementation, monitoring and evaluation studies.

Effective and powerful organizational information are important. These can create a strong information system allowing to follow-up overall activities, dealings, structures and institutional information. This will enable traditional handicrafts industry owning a modern tool to help make appropriate decisions. Choices, strategic directions, local development programs and resources management are available in various regions of Algeria. Traditional handicrafts industry has been mostly left unattended in many development initiatives. Its inclusion in development agenda initiated since 2005 for constructing an information system. This system was developed to transform large effects on technical and administrative levels. Regulatory initiatives to support institutions were also relevant in this regard.

To ensure excellence in traditional handicraft industry is also relevant. The Algerian government has allocated large investments to this industry during periods of 2005-2009 and 2010-2014 to accomplish many of the structural facilities accompanied to frame and deal this sector to help artisans and professionals. Completed structures are mentioned as chambers of traditional crafts, valuing local skills centers, workshops for training and production, wool buying centers, stamping centers, spaces for display and sale. Franchises in traditional handicrafts industry are designed to bring dynamics and stimulating projects for local economic development. The valuation of local craft production and promotion of cultural and tourism wealth also becomes relevant in this perspective.

The Handicraft Development Scheme of 2020 is expected to have important effects as to improve the quality of traditional handicrafts industry, increasing the diversity of products as a component of satisfaction of customers and tourists; contributing to the creation of new craft activities; involving rural population in this industry; contributing to develop a competitive industry to enter into foreign markets. These are general contents of the traditional handicrafts industry 
development strategy by 2020. This set of strategies has already passed five years of application that half of the time to make partial evaluation.

\section{Partial Evaluation of Traditional Handicrafts Industry DEVELOPMENT STRATEGY BY 2020:}

This part provides some figures and indicators showing the progress of this set of strategies to achieve set objectives. Among many others, some indicators outline establishing craft activities, jobs, training, local production system, development of craft activities and employment creation. Data in these tables are collected in person from the responsible ministry as mentioned in each of the tables.

Table 1: Evolution of annual activities and Employment creation in traditional handicrafts industry (source: The Ministry of Tourism and Handicraft, 2015).

\begin{tabular}{|l|l|l|l|l|l|l|}
\hline Year & 2010 & 2011 & 2012 & 2013 & 2014 & $\begin{array}{l}\text { Total until June 30, } \\
2015\end{array}$ \\
\hline $\begin{array}{l}\text { Created } \\
\text { handicraft } \\
\text { activities }\end{array}$ & 20822 & 32717 & 40718 & 51640 & 63999 & 307882 \\
\hline $\begin{array}{l}\text { Number of } \\
\text { created } \\
\text { employment }\end{array}$ & 50698 & 83440 & 105052 & 138028 & 183507 & 796725 \\
\hline
\end{tabular}

After the nearly half time of application of Traditional Handicrafts Industry Development Strategy by 2020, it has been established that until the 30th June, 2015, a total of 307, 882 activity craftsmen was created. This set of strategy created 122, 882 new activity craftsmen out of 230, 00, 00 activity craftsmen target. Thus, the target has been achieved by $53.42 \%$ till date. In comparison to the targeted creation of 570000 new employments, this set of strategies has been able to create 426,725 new employments. This target has been achieved by $85 \%$. This confirms the effectiveness of measures and incentives in place to stimulate and develop traditional industry sector.

Table 2: Evolution in configuration management (source: The Ministry of Tourism and Handicraft, 2015).

\begin{tabular}{|c|c|c|}
\hline \multirow{2}{*}{ Year } & \multicolumn{2}{|c|}{ Configuration Management } \\
\cline { 2 - 3 } & Number of Sessions & Number of Trainees \\
\hline 2012 & 93 & 1232 \\
\hline 2013 & 62 & 860 \\
\hline 2014 & 238 & 3745 \\
\hline
\end{tabular}

The above table is about configuration management from a total of 5837 individuals within three years. A small number of them, when compared to the number of activities and positions were created during this period of time. For technical configuration, a total of 4260 individuals from the beginning of 2013 until June, 2015 has been considered. Here are also a very small number of components and this requires work to raise awareness and encourage craftsmen and workers in the traditional manufacturing sector. The importance of training, technical and management knowledge is important. 
Table 3: Direct support for craftsmen (source: The Ministry of Tourism and Handicraft, 2015).

\begin{tabular}{|l|l|l|}
\hline Year & 2013 & 2014 \\
\hline Granted amount & $223,586,508$ & $567,676,014$ \\
\hline Beneficiary number & 756 & 1685 \\
\hline
\end{tabular}

The above table presents the number of beneficiaries during 2013 and 2014. This number amounted to 2441 beneficiaries. The number has surpassed the establishment of activities during this period. 100000 activity craftsmen and beneficiaries are small in number. Several reasons acted as obstacles in regards to funding. It is more important not to harmonize the existing funding formulas with peculiarities of traditional handicrafts industry. Financial terms that exclude many artisans, as well as loan interests are less likely to get importance. All of these are impediments to the development of traditional handicrafts industry.

Table 4: Evolution of the local production system (source: Ministry of Tourism and Handicraft and urban configuration, 2015).

\begin{tabular}{|l|l|l|l|l|}
\hline Year & $\begin{array}{l}\text { Number } \\
\text { involved }\end{array}$ & $\begin{array}{l}\text { Transaction } \\
\text { number }\end{array}$ & $\begin{array}{l}\text { Transaction } \\
\text { value (DA) }\end{array}$ & $\begin{array}{l}\text { Collective } \\
\text { purchase } \\
\text { value (DA) }\end{array}$ \\
\hline 2011 & 1132 & 330 & 38833500 & 5842000 \\
\hline 2012 & 1859 & 220 & 140735549 & 6580000 \\
\hline 2013 & 1863 & 70 & 47900000 & 3050000 \\
\hline 2014 & 2283 & 216 & 607486468 & 4500000 \\
\hline
\end{tabular}

The above table notes that the number of those involved in local production systems is small compared to the number of activities. However, the given number of transactions that they get is significant. For example, 2011 exceeded 330 dealing and this shows the importance of establishing local production systems. This should be encouraged and awareness needs to be set up in order to develop traditional handicrafts industry. Observed indicators show that traditional handicrafts industry has achieved considerable success regarding the establishment of activities and employment creation results. This also represents potentials of this sub-sector in regard to the establishment of value-addition and new employment creation. It is difficult to avoid specific shortcomings including what have been observed as indicators, configuration and private funding. A large turnout from artisans and traders in this sub-sector calls for the development of new procedures to encourage and attracted them to related mechanisms.

\section{CONCLUSION:}

This study aims to explore diversities of traditional handicrafts industry of Algeria followed by evaluative explanations of development programs undertaken. Traditional handicrafts industry has known considerations to develop and improve its contribution to the development of a country as Algeria. Planners put their development efforts during the period 2003 -2020. They also have worked hard to upgrade the competitive traditional products. They also have increased capacities through a lens of focus on supporting entrepreneurial and training initiatives in this area. In addition to the establishment of a media convergent craftsmanship to communicate and interact, traditional handicrafts industry has resulted to represent traditional private industrial rooms. Through the evaluation of results achieved by the taken development schemes, this paper finds a significant increase in activities and new employment creation indicating the effectiveness of policies and actions taken. Still some shortcomings hinder the development of this sub-sector from desired development. The most important is the absence of appropriate funding 
mechanisms for contributing to the traditional handicraft industry. In addition, the study explores calls for more efforts, searching of ways and measuring necessary initiatives to avoid these obstacles. The study concludes that, traditional handicrafts industry of Algeria commensurate immense potentials. This paper is mainly descriptive and descriptive accounts have been a limitation, while more primary data and information could possibly enhance and deepen critical arguments.

\section{REFERENCES}

1. Ben Zaror, S. (2004). The Problem of the Traditional Export Product - Look at the Faculty. Craftsman Magazine, 3, pp. 7-17.

2. Ben Amoudi, D. (2012). The Strategy of Development the Traditional Industries and Crafts Sector in Algeria in the period 2003-2010. Ouargla: University of Ouargla.

3. Ben Zaror, S. (2007). The Problem of Marketing in Traditional Crafts Industry. Algiers: The National Chamber of Traditional Handicraft Industry Report.

4. General Secretariat of the Government of Algeria (1996). Order No. 01-96 (dated 01.10.1996) (issued on 14.1.1996). The Official Gazette, 3. Algriers: General Secretariat of the Government.

5. National Chamber of Industry and Traditional Crafts (2009). The Evolution of the Traditional Handicraft Industry and Crafts Sector in Algeria 1962-2009. Algiers: National Chamber of Industry and Traditional Crafts.

6. Saadoun, B. (2003). Role of The Tourism Sector in the Development of Traditional Crafts industry in Algeria. The International Forum on the Reality and the Future of Traditional Handicraft Industry in Algeria. Bechar: The House of Culture. The 20th December -21st December, 2003.

7. Sdiqi, S. (2002). Push Traditional Carpet Exports Algerian Application of International Marketing Approach. Algiers: The University of Algeria.

8. Shiban, A. (2009). The Role of Small and Medium Enterprises in Economic Development - The Case of Traditional industry and Crafts in Algiers. Algiers: The University of Algiers.

9. The Ministry of Tourism and Handicraft (2011). Handicraft Development Action Plan Horizon 2020 (Summary). Algiers: The Ministry of Tourism and Handicraft.

10. The Ministry of Traditional Small and Medium-Sized Enterprises and Traditional Industry (2009). Industry - The Future of the Project. The National Sessions of Traditional Handicraft Industry and the Results of the Facts. Algiers: The Ministry of Traditional Small and Medium-Sized Enterprises and Traditional Industry, The 22nd December -23rd November, 2009.

\section{Author Biographies}

Fatiha Bouziane (e-mail: fati_bouziane@ hotmail.fr) is a PhD candidate at University of Algiers, Algeria. She is a fluent speaker of the Arabic, the French and the English. Her PhD research uniquely aligns rural development with sustainable development and poverty contexts in Algeria. Prior to this, she completed the Master in Management also from the same university. She served the University of Chlef and the Vocational Training Center at Djelida as a Teaching Assistant and as a Teacher, respectively. She presented research paperes at the University of Khemis Miliana and the University of Djelfa. She has research interests in rural tourism, agricultural tourism and local development through tourism initiatives.

Azizul Hassan (e-mail: M.Hassan15@outlook.cardiffmet.ac.uk) is a member of the Tourism Consultants Network of the UK Tourism Society, and is currently working towards a $\mathrm{PhD}$ at Cardiff Metropolitan University. His main areas of research are: technology-supported marketing in tourism; innovative marketing dynamics; destination branding in tourism; cultural heritage tourism; heritage interpretation; and sustainable management/marketing alternatives for cultural heritage industries. He is a regular reviewer of the International Journal of Human Resource Management, the International Journal of Ecotourism and the eReview of Tourism Research (eRTR) and The International Interdisciplinary Business-Economics Advancement Journal. 